\section{Ujevn bok om amerikansk psykiatri}

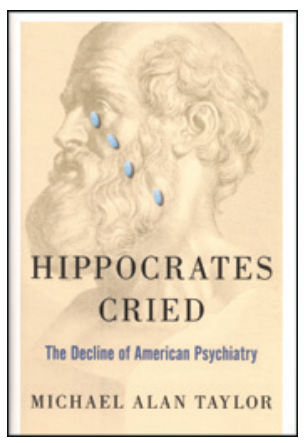

Forfatteren er psykiater, men beskriver seg som nevropsykiater. Han har, siden han var ferdig utdannet som lege i 1965, arbeidet som kliniker og forsker ved flere amerikanske, akademiske institusjoner. I denne boken henvender han seg i første rekke til sine kolleger i USA, men alle med tilknytning til psykiatrien vil kunne lese den med et visst utbytte.

Taylor mener åpenbart at alle psykiske lidelser er uttrykk for hjernesykdommer og at psykiatrien burde integreres i nevrologien. I sin beretning om psykiatrien gjennom de siste 40-50 årene går han særlig til angrep på psykoanalysen, medisinalindustrien og de nyere DSM-klassifikasjonene. Fortellingen om de siste årtienes amerikanske psykiatri er ispedd personlige opplevelser og sykehistorier der pasienter med en psykiatrisk diagnose egentlig var nevrologiske kasus. Den feilaktige diagnostikken skyldes i stor utstrekning manglende nevrologisk undersøkelse og diagnosemanualen DSM. Denne kokebokdiagnostikken, hvor man teller opp antall kriterier for å stille en diagnose, har ført til at leger i utdanning og ferdige psykiatere ikke setter seg inn i den rike psykopatologiske litteraturen som er utforsket tidligere av fremtredende psykiatere. Dessuten bruker man for lite EEG og CT i diagnostikken. Behandlingen er også blitt dårligere de siste tiårene, for den ofte er overlatt til primærleger, psykologer, sosionomer og sykepleiere.

Fortsatt henger psykoanalytisk tankegods igjen i undervisningsprogrammer, og på grunn av den massive reklamen fra medisinalindustrien bruker psykiatere de nyere SSRI-medikamentene i stor skala der «gamle» trisykliske antidepressiver som er langt billigere, ville gjort samme nytte. Det eneste som skiller de eldre fra de nyere, er bivirkningsprofilen. Det samme gjelder antipsykotiske medikamenter, der de nyere ikke er bedre enn de klassiske fra midten av 1950-60-årene. Endelig bruker man for lite elektrokonvulsiv behandling (ECT).

Forfatteren har en rekke gode argumenter, men overdriver til dels voldsomt. Den største svakheten som irriterer anmelderen, er den direkte feilaktige fremstillingen av amerikansk psykiatrisk historie. Man kan få inntrykk av at psykoanalysen har dominert amerikansk psykiatri fra 1930-årene, noe som ikke er riktig. Helt frem til 1940årene var det den somatisk orienterte asylpsykiatrien som var toneangivende i Amerika. Det var først etter siste verdenskrig at psykoanalysen mer og mer vant frem og nådde sitt høydepunkt i 1950-60årene, med en stadig tilbakegang fra 1970-årene. Ingen psykiater kunne bli sjef for en prestisjefylt psykiatrisk institusjon i 1960-årene uten å være psykoanalytiker. I dag er disse stillingene overtatt av biologisk orienterte psykiatere med bakgrunn i farmakologi, biokjemi, nevrologi og hjernebildediagnostikk. Den brede kliniske bakgrunnen som kunne være ønskelig for ledere av slike institusjoner, finnes ikke. Jeg hadde ventet at forfatteren hadde fortalt også den historien.

\section{Den store gule oppslagsboken om reisemedisin}

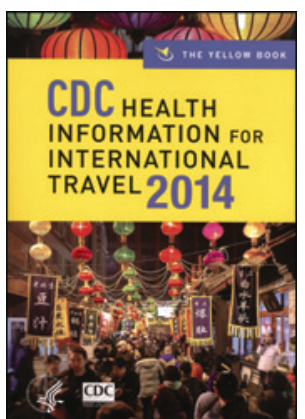

Gary W. Brunette, red.

CDC health information for international travel 2014

653 s, tab, ill. Oxford: Oxford University Press, 2013. Pris GBP 33

ISBN 978-0-19-994849-9

Det finnes et vell av reisemedisinske lærebøker med overlappende innhold, men det er godt å ha en med autoritet i ryggen når vi gir våre anbefalinger. The yellow book fra Centers for Disease Control and Prevention (CDC) er en slik. Den kommer i ny utgave annethvert år, og sammen med WHOs International travel and health og Folkehelseinstituttets utgivelser gir den basiskunnskap om reisemedisin. Målgruppen er leger, sykepleiere og farmasøyter som gir vaksiner, resepter og råd til folk som skal ut og reise. Den tjener også som oppslagsbok for reiselivsbransjen og organisasjoner med medarbeidere stasjonert utenlands.

Reisemedisinen omtales i hele sin bredde, herunder konsultasjon før reiser, reisende med spesielle behov, de viktigste infeksjonssykdommene som kan erverves på reise, inkludert oppdaterte utbredelseskart, og utredning av hjemvendte reisende. Det er et svært nyttig kapittel om utvalgte turiststeder, som dekker de fleste reisemålene vi kommer ut for i den reisemedisinske hverdag. Her beskrives aktivitetene de reisende bedriver på de ulike destinasjonene og hvilke risikoer de utsettes for, også de som ikke har med infeksjoner å gjøre.

Dette er en god lærebok i reisemedisin, men ved utredning av infeksjoner hos reisende må den suppleres med lærebøker i infeksjonsmedisin. Gode insidenstall som gir oss grunnlag for å vurdere sykdomsrisikoen for den enkelte reisende er mangelvare, og denne utgivelsen gjør dessverre lite for å avhjelpe dette. Når det gjelder vaksineanbefalinger og malariaprofylakse, er det til dels store forskjeller mellom amerikanske og norske anbefalinger. Mens vi bare unntaksvis anbefaler forebyggende malariamedisiner utenfor Afrika, anbefales her malariamedisin stort sett overalt hvor WHOs verdenskart viser at malaria forekommer. Folkehelseinstituttet og CDC har tilnærmet identiske anbefalinger for barnevaksinene, gulfeber, hepatitt A, japansk encefalitt, meningokokksykdom, tyfoidfeber og rabies, men mens CDC anbefaler de fleste reisende å overveie hepatitt B-vaksine, anbefaler Folkehelseinstituttet vaksinen bare til dem som har ekstra risiko for hepatitt B. Anbefaling om selvmedisinering med antibiotika for alle med turistdiaré er heller ikke i tråd med norske retningslinjer.

The yellow book anbefales til alle som driver med reisemedisin og vaksinasjon. Den må imidlertid suppleres med litteratur basert på norske anbefalinger. Norske reisemedisinere oppfordres til å legge Folkehelseinstituttets anbefalinger til grunn for sin praksis slik at publikum ikke får ulike råd avhengig av hvilket vaksinasjonskontor de henvender seg til.

Hele boken finnes tilgjengelig gratis i nettversjon: www.cdc.gov/travel/yellowbook.

Gunnar Hasle

Reiseklinikken 